\title{
THE EARLY MEDIEVAL STIRRUP FROM BRIBIR
}

\section{ANTE MILOŠEVIĆ}

\author{
UDC: $902.2(497.581 .2)$ \\ 903.22(497.581.2)"08/11" \\ Original scientific paper \\ Manuscript received: 09. 02. 2017. \\ Revised manuscript accepted: 26. 02. 2017. \\ DOI: 10.1484/J.HAM.5.113760
}

\author{
A. Milošević \\ Muzej hrvatskih arheoloških spomenika \\ S. Gunjače 3 \\ HR-210oo Split, Croatia \\ ante.milosevic@st.t-com.hr
}

The text discusses an iron ornamented stirrup from Bribirsk Glavica. This finding do add a great deal to the picture of the Bribir past, from the $9^{\text {th }}$ to the $12^{\text {th }}$ century, and yet in their fundamental cultural indicators do not depart from the framework that we know of for this site, from earlier work, and from other finds of the early medieval period. Analysis in terms of typology and chronology was used to try to show the different influences on the making of this objects or their direct import from the then bigger workshop centres in Central Europe or the Byzantine Empire. His quality and excellence of workmanship tellingly documents the high level of life in Bribir in the centuries in which the nobiles Breberienses started their economic, military and political rise.

Key words: Central Dalmatia, Bribirska Glavica, combat equipment, stirrup, Early Middle Ages, Byzantium, Carolingian period

Bribirska Glavica in Central Dalmatia (ancient Varvaria - medieval Breberium - today Bribir) is well known to be a prolific archaeological site with a long period of existence, from the prehistoric Liburni to the modern age (fig. 1). It has been excavated with varying degrees of intensity for more than a century, but the pick and trowel have not been blessed by fortune. First of all, after the ending of World War I, when, in the new Kingdom of the Serbs, Croats and Slovenes, the aim was to put a stop to the research of all finds that had anything Croatian about them. The second time came in World War II, when, in the same key, the museum building on Bribir was burned and the heritage objects from it were tipped down to the foot of the hill. The third time, again for the same reasons, the archaeological heritage from the museum builds were dumped over the surrounding meadows, with anything that was recognisable in form or appearance having been previously stolen. Such experience from the past occasionally led to archaeological finds being moved from Glavica to safer places, firstly to the Museum of Croatian Archaeological Monuments in Split, and then to Šibenik Municipal Museum. Since these transfers were almost always made in a hurry because of some impending threat, not enough care was always taken about the information that should have accompanied given finds. Thus during the course of time in these museums, collections were formed in which the objects wanted the basic accompanying data, save for the fact that they derived from Bribir. From such holdings that came into being in the Museum of Croatian Archaeological Monuments (MCAM), a few items of weaponry and combat equipment have been picked out and are here published, items that in our opinion are important for an understanding of the Bribir past as a whole. One is a decorated stirrup from horse harnes ${ }^{1}$.

An iron stirrup was noticed quite recently among noninventoried items kept in a box in the Museum on which the word "Bribir" was written, with no additional data. It has a markedly triangular shape (fig. 2). On the upper end it finishes with a plate of a flat pentagonal shape on which there is an elongated rectangular slot through which to pull the strap. In the place where the strap plate joins with the arms of the stirrup are two expansions with circular perforations. We assume that these have no practical purpose, but are there merely to balance the thickening at the end of the arms aesthetically. The right arm is broken in the centre. The tread of the stirrup is hammered out so as to be rectangular and slightly curved. The whole of the outside of the stirrup is decorated with damascene work, with fine gold and silver wire. Traces of decoration with silver wire on the arms are minimal and are only preserved in a few places, while the external side of the wrought iron tread is decorated with a fine, reticular, diagonally placed ornament in the same material. The most complex decoration is found on the outer side of the strap plate ${ }^{2}$. The central motif is made in silver, and composed of a triangular shape created by two stylised (headless) bird bodies. At the top of this triangle is a crowned male head. Part of the decorative composition of the triangular shape on the strap plate consists of two long bands with a twisted volute at the top placed opposite to each other. These two are done in damascene work with silver wire, just like the edges on all the perforations of the plate. The rest of the plate is filled with plant and tendril ornaments done in damascene work with gold wire 3 .

\footnotetext{
${ }^{1}$ This text is part of the article published in: A. MILOŠEVIĆ, Iz armatorija srednjovjekovnog Bribira / From the Armoury of Medieval Bribir, Starohrvatska prosvjeta, ser. 3, sv. 43, Split, 2015, pp. 49-90.

${ }^{2}$ The stirrup from Bribir was put into excellent order through a creative conservation-restoration procedure by Dalibor Popovič, museum restorers in the Museum of Croatian Archaeological Monuments (MCAM).

3 The overall height of the stirrup is $21.8 \mathrm{~cm}$, the maximum breadth is $14.6 \mathrm{~cm}$, and the tread is wrought to a depth of $3.1 \mathrm{~cm}$. The height of the decorated plate is $6.5 \mathrm{~cm}$, and its width is $6.3 \mathrm{~cm}$. Inv. no. 18.202 MHAS, Collection of Medieval Weaponry and Cavalry Equipment.
} 


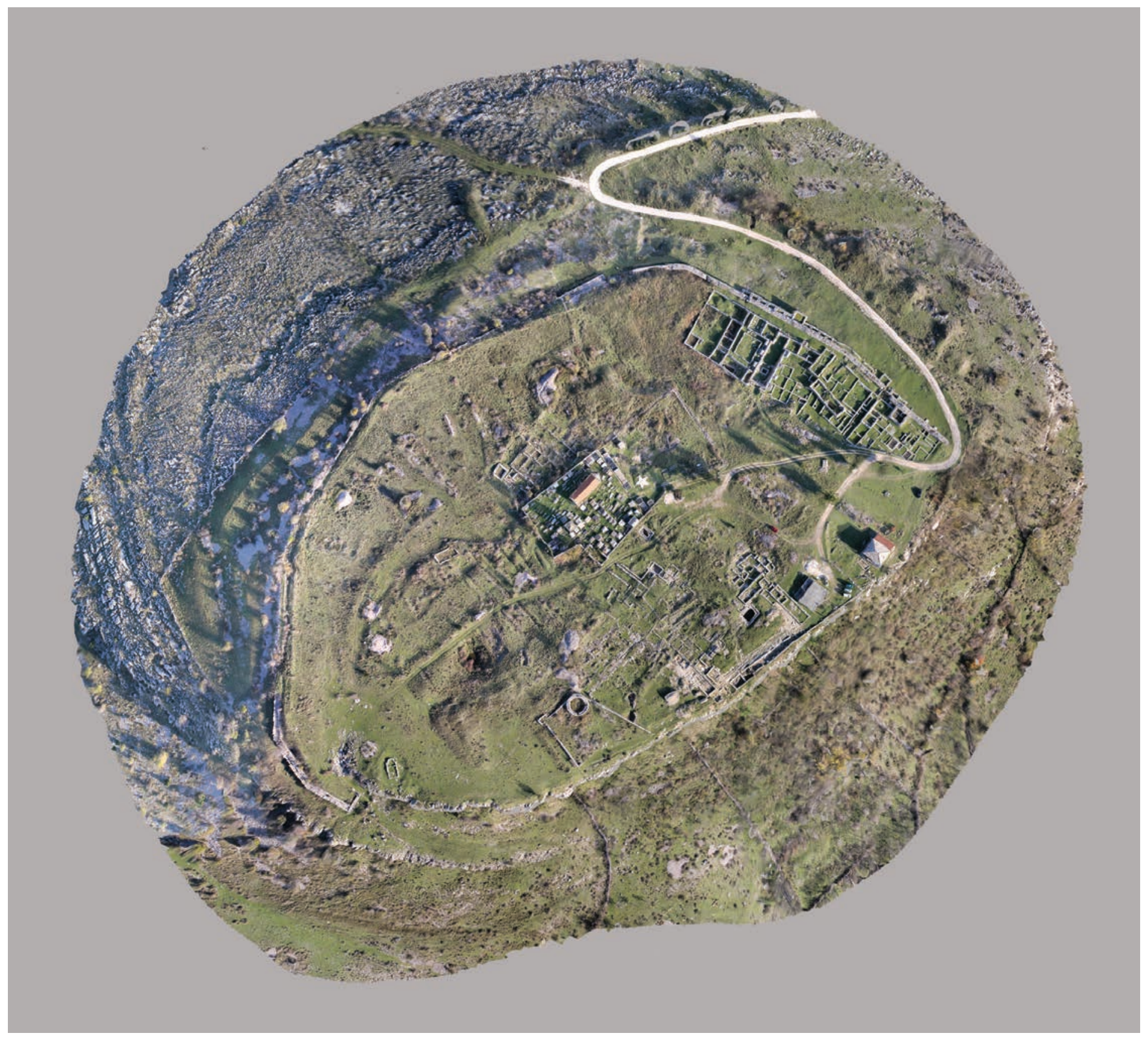

Fig. 1. PhotoScan capture of a photogrammetric model of Bribirska glavica in Central Dalmatia, 2012 (created: A. Milošević, V. Ghica)

The decorated iron stirrup is a very particular find. It was put into the collection of the MCAM without any data about the context of the find; all that was written was that it derived from Bribir. In the coastal area of early medieval Croatia, stirrups are a very rare find, and apart from this Bribir example, we know of just one more from Bribir while two iron stirrups were found at an early medieval castrum in Podgradina, on the western edge of Buško Blato [lake] $]^{4}$. And the other Bribir find too is unaccompanied by any ancillary archaeological information. It was published in a short and general text some thirty years ago ${ }^{5}$, and from the photographs appended it can be seen that it belonged to the form of round stirrup with a rectangular lug and a wrought circular plate for the tread. The publication assumed justly that it belonged to types characteristic of the $10^{\text {th }}$ century ${ }^{6}$. In the case of the stirrup from Buško Blato 7 , we are confronted with

\footnotetext{
${ }_{4}^{4}$ These are accidental finds uncovered as a result of metal-detector searches. They were bought for the MCAM in 2011, and a given as inv. no. 18.0oo and 18.001 in the Collection of Weaponry and Military Equipment. The size of the complete example is $16.3 \times 11.3 \mathrm{~cm}$, and that with a broken lug is $15.8 \mathrm{x} 9.9 \mathrm{~cm}$. ${ }^{5}$ M. DRAGIČEVIĆ, Metalni proizvodi, in: Bribir u srednjem vijeku, (ed. A. Milošević), Split, 1995, p. 76 with figure (inv. br. 9124 - Collection of Medieval Weaponry and Cavalry Equipment, size 16.9 x $15.6 \mathrm{~cm}$ ). In the inventory of MCAM, n. 8906 in the same collection, it says that another stirrup was found in Bribir, but in fact it was the hilt of a Gothic dagger. See also A. MILOŠEVIĆ, Iz armatorija, fig. 14.

${ }^{6}$ A form that was more common in central and eastern Europe (J. HAMPEL, Alterthümer des frühen Mittelalters in Ungarn. Vol. 1, Braunschweig, 1905, pp. 235-237. - A. RUTTKAY, Waffen und Reiterausrüstung des 9. bis zur ersten Hälfte des 14. Jahrhunderts in der Slowakei, II, Slovenska Archeologia 24/2, Bratislava, 1976, pp. 354-355, fig. 74, tip IV, 10. stoljeće. - А. Н. КИРПИЧНИКОВ, Снаряжение всадника и верхового коня на Руси IX- ХІІІ вв. Москва, 1973, p. 92, fig. 29, tip 1, $10^{\text {th }}$ century. - В. ЙОТОВ, Стремената на прабългарите, Добруджа 24-25, Добррич-Силйстра, 2013, pp. 125-134, they are dated to the second half of the $10^{\text {th }}$ and the first half of the $11^{\text {th }}$ century.
}

${ }^{7}$ A. MILOŠEVIĆ, Iz armatorija, fig. 15. 


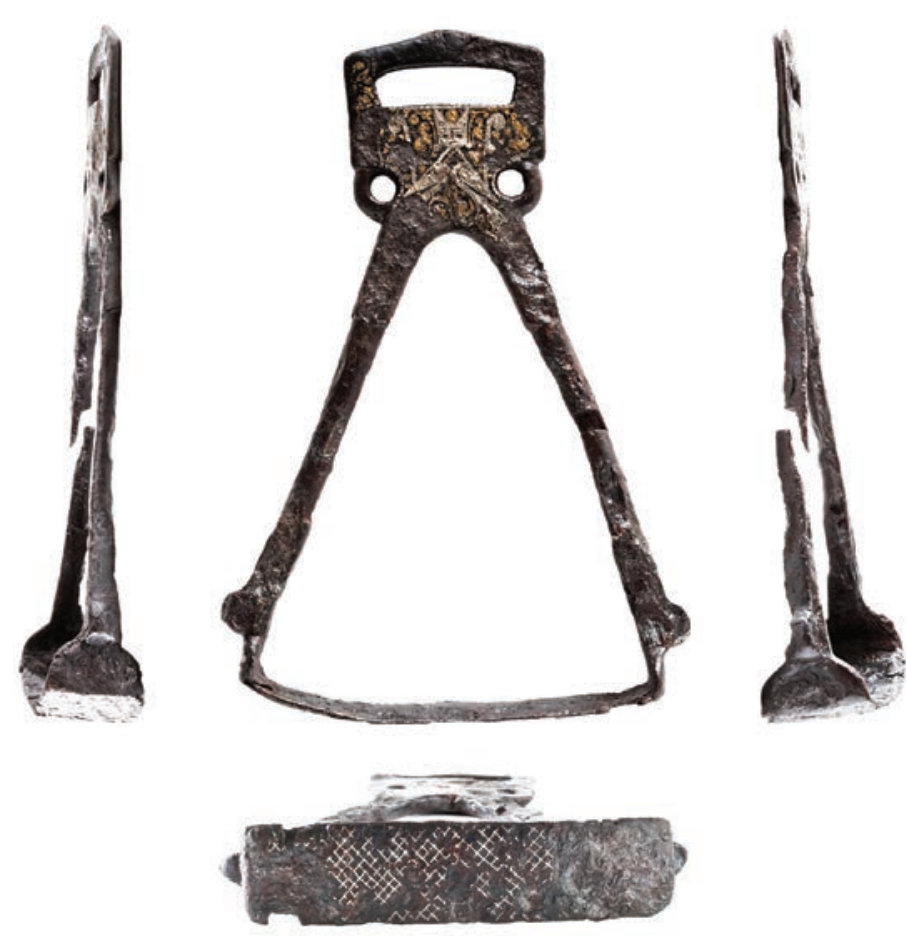

Fig. 2. Bribir stirrup in a view from all around (photograph: A. Z. Alajbeg)

a simple, iron, oval stirrup of the kind found in several sites in central Europe, primarily in the Carpathian basin ${ }^{8}$. On the whole they are ascribed to the late Avar cultural horizon and are dated to the end of the $8^{\text {th }}$ and the beginning of the $9^{\text {th }}$ century. There are direct analogies from today's Croatia in examples from devastated graves in Bogojevci not far from Dalj near Osijek ${ }^{9}$ and from gravel in Prelog ${ }^{10}$. In the SavaDrava inter-riverine area there are several other graves of the same time that have been found in which there are goods of late Avar stirrups, but these have no lugs for the leathers at the top, but a rectangular plate with a hole ${ }^{\mathrm{n}}$, rather like the Bribir example. An exception among the stirrups of this area is a find from the site of Diven by Cirkovljani not far from Prelog. During dredging for sand in the river at this site, a grave was destroyed from which an early Carolingian $K$-type sword and one damaged iron egg-shaped stirrup with a wrought tread and a loop for the leather, placed at right angles to the arc of the stirrup ${ }^{12}$. This example, from the end of the $8^{\text {th }}$ and early $9^{\text {th }}$ century, like the sword, belongs in the early Carolingian cultural circle, with many analogies in the Germanic and Viking areas ${ }^{13}$.

A find of a pair of iron silver-damascened stirrups from the Sava-Drava inter-riverine area is interesting. With ten more luxury items, they were part of an inventory from one of two equestrian graves destroyed around 190o. Today they are in a museum in Budapest ${ }^{14}$. Z. Vinski hypothesises a date for them of, at the earliest, the middle or the second half of the $7^{\text {th }}$ century, that is, the "central phase of Avar domination"15. Having drawn attention to the exceptional rarity of the manner in which these Baranya stirrups were damascened with silver, Vinski nevertheless left the discussion of the find unfinished. He stated that this was a technique that was used very seldom in the Carpathian basin, but that it was very common in central Europe and Scandinavia, mainly among equestrian requisites of the $7^{\text {th }}$ century, on bits and spurs ${ }^{16}$. The find was then discussed in greater detail and at greater length by $\mathrm{E}$. Garam, who on the whole supported Vinski's determination and dating of the culture and time ${ }^{17}$. We would nevertheless observe that the technique of damascening with silver and gold wire is not typical only of the $7^{\text {th }}$ century for - primarily in cavalry equipment - it was used in the later centuries of the Middle Ages, as shown by finds from other parts of Europe, and also

${ }^{8}$ J. HAMPEL, Alterthümer des frühen Mittelalters 1, pp. 217-242. - N. PROFANTOVÁ, Awarische Funde aus den Gebieten nördlich der awarischen Siedlungsgrenzen, in: Awarwen Forschungen, vol. II, (ed. F. Daim), Vienna, 1992, pp. 636-637.

9 Z. BOJČIĆ, Pregled istraživanja i rasprostranjenost ranosrednjovjekovnih nalaza u istočnoj Slavoniji i Baranji, in: Arheološka istraživanja u istočnoj Slavoniji i Baranji (Izd. HAD-a 9), (ed. N. Majnarić-Pandžić), Zagreb, 1984, p. 216, fig. 2.

${ }^{10}$ Ž. TOMIČIĆ, Rezultati ranosrednjovjekovnih arheološklih istraživanja u Međimurju i varaždinskoj regiji. in: Arheološka istraživanja u sjeverozapadnoj Hrvatskoj (Izd. HAD-a 2), (ed. Ž. Rapanić), Zagreb, 1978, p. 212. fig. 4. See also A. MILOŠEVIĆ, Iz armatorija, fig. 16.

${ }^{1 "}$ K. VINSKI GASPARINI - S. ERCEGOVIĆ, Ranosrednjovjekovno groblje u Brodskom Drenovcu, Vjesnik Arheološkog muzeja u Zagrebu, ser. 3, vol. 1, Zagreb, 1958, pp. 146, 155-156, T. IX/1-2, XII/1-2, XII/1-2. - Hrvati i Karolinzi. Katalog. (Ed. A. Milošević), Split, 200o, pp. 84-86, cat. entry II.2b-c, II. 3b-c, II. 4b-c (graves 1,3 and 14 from Brodski Drenovac, early $9^{\text {th }}$ century), p. 89, cat. entry II. 8 a (from a ruined grave in Bogojevci by Dalj, end of the $8^{\text {th }}-$ early $9^{\text {th }}$ century), p. 110, cat. entry II. 56c (grave 4 from Kruge site in Zagreb, end of the $8^{\text {th }}$-early $9^{\text {th }}$ century). For finds from Kruge, Zagreb, cf. also K, SIMONI, Zagreb i okolica u ranom srednjem vijeku in: Arheološka istraživanja u Zagrebu i njegovoj okolici (Izd. HAD-a 6), (ed. Ž. Rapanić), Zagreb, 1981, pp. 157-16o, fig. 4/4. ${ }^{12}$ Ž. TOMIČIĆ, Rezultati ranosrednjovjekovnih arheološklih istraživanja u Međimurju, p. 212. - Ž. TOMIČIĆ, Prilog istraživanju karolinškog oružja u Međimurju i varaždinskoj regiji, Starohrvatska prosvjeta, ser. 3, vol. 14, Zagreb, 1984, pp. 216-223, fig. 6. - Hrvati i Karolinzi. Katalog, p. 10o, cat. entry II. 28. See also A. MILOŠEVIĆ, Iz armatorija, fig. 17.

${ }^{13}$ Cf for instance:F. STEIN, Adelsgraber des Achten Jahrhunderts in Deutschland. Berlin, 1967, p. 85. - A. RUTTKAY, Waffen und Reiterausrüstung, pp. 353-356. - W. A. SEABY - P. WOODFIELD, Viking Stirrups from England and their Background, Medieval Archaeology 24, London, 1980, pp. 87-122. - M. SCHULZE DÖRRLAMM, Untersuchungen zur Herkunft der Ungarn und zum Beginn ihrer Landnahme im Karpatenbecken, Jahrbuch des RömischGermanischen Zentralmuseums Mainz 35/2, Mainz, 1991, pp. 425-438. - Š. KARO, Die Typologie der frühmittelalterlichen Steigbügel aus slowenischen Fundorten, in: Zborník na počest' Dariny Bialekovej, (ed. G. Fusek), Nitra, 2004, pp. 165-173. - N. GOSSLER, Die mittelalterlichen Steigbügel aus dem Berliner Bestand der Prussia-Sammlung (ehemals Königsberg/Ostpreußen) - Studien zu Typologie, Chronologie und Kulturgeschichte, Acta Praehistorica et Archaeologica 45, Berlin, 2013, pp. 109-215.

${ }^{14}$ J. HAMPEL, Alterthümer des frühen Mittelalters 2, pp. 844-846. - J. HAMPEL, Alterthümer des frühen Mittelalters 3, Taf. 498-500 (whole find), stirrups on plate 499/1-2, It is questionable whether this is a grave unit or finds from several ruined graves. Good quality drawings in: Ž. TOMIČIĆ, Panonski periplus. Arheološka topografija kontinentalne Hrvatske. Zagreb, 1999, p. 227. See also A. MILOŠEVIĆ, Iz armatorija, fig. 18.

${ }^{15} \mathrm{Z}$. VINSKI, O nalazima 6. i 7. stoljeća u Jugoslaviji s posebnim obzirom na arheološku ostavštinu iz vremena prvog avarskog kaganata, Opuscula archaeologica 3/1, Zagreb, 1958, pp. 26, 30-31, T. XI/9-10.

${ }^{16}$ Z. VINSKI, O nalazima 6. i 7. stoljeća, p. 50, n. 157a.

${ }^{17}$ É. SZ. GARAM, De Fund von Vörösmart im archäologischen Nachlaß der Awarenzeit, Folia archaeologica 33, Budapest, 1982, pp. 187-212. 
from Dalmatia ${ }^{18}$ and from what was once the Duchy of Greater Moravia ${ }^{19}$. It is our opinion then that the stirrups from Zmajevci, typologically, can be compared with examples found in the late Avar equestrian grave at the site of Kruge, Zagreb, which puts them chronologically in the last quarter of the $8^{\text {th }}$ or in the early $9^{\text {th }}$ century, but we shall leave this debate for some other occasion.

On the whole, there is a widespread opinion that the use of metal stirrups ${ }^{20}$, with a reflex (composite) arch, is the most important achievement in the development of military strategy and warfare on the medieval battlefield ${ }^{21}$. An opposite opinion is given by P. P. Azbelev, who assumes that in the earliest phase of the existence of stirrups -which at the beginning were created as a simple and practical seating for the feet of the rider - had no kind of connections with pushing the state-of-the-art in warfare. He thinks that they were originally just riding tack for the aristocracy, i.e., that this was equestrian equipment that was foreign to the nomad tradition ${ }^{22}$. He gives examples of proto-stirrups that go back to the first century CE, for example, on a seal from Pakistan of the $1^{\text {st }}$ century, or on a bronze vase from the valley of Kullu in northern India of the $3^{\text {rd }}$ century (fig. 3.1-2) 2 $^{23}$.
Archaeologists and historians have long debated and wondered about its origin. On the whole, the opinion prevails that the stirrup was first used by the Chinese and other nomadic nations in the Asian steppes as early as the $5^{\text {th }}$ century (fig. $\left.3.3^{-5}\right)^{24}$ and that it was brought to Europe by the Avars in the last decades of the $6^{\text {th }}$ and early $7^{\text {th }}$ century ${ }^{25}$. Proponents of the Avar theory build this assumption on the fact that in several cases stirrups were found in the Avar graves along with coins from the Byzantine emperors Justinian (518-527) and Phocas (602-610). After the Avars had conquered the Carpathian basin, for some time, a new territorial unity was created, a certain social and economic coherence and stability that from time to time favoured them having more vigorous contacts with their neighbours ${ }^{26}$.

It is also supposed that these conquests set off a new migration of the Langobards to the west, and thus the transfer of the stirrup as an important part of the accoutrements of the cavalry, as confirmed by finds of stirrups in Langobard graves in Italy and contemporaneous Bavarian finds in southern Germany ${ }^{27}$.

A different group of experts, inspired by the book of $\mathrm{L}$. White ${ }^{28}$, point to the importance of the Byzantine milieu as

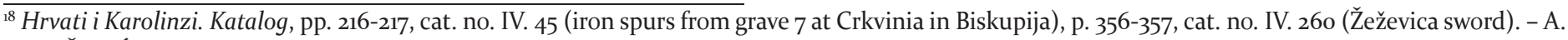
MILOŠEVIĆ, Novi mač iz Koljana u svjetlu kontakata s nordijskim zemljama u ranom srednjem vijeku, Histria Antiqua 21, Pula, 2012, pp. 459-470.

${ }_{19}$ Great Moravia and the Beginnings of Christianity. (Ur. P. Kouřil), Brno, 2014, p. 344 (Mikulčice, K-swords), p. 369 (Mikulčice, spurs with set), p. 373 (Ducove, spur), p. 374 (Preostějov stirrup with damascened arms) and other finds, mostly from the $9^{\text {th }}$ century.

${ }^{20}$ It is assumed that the prototypes of the metal spurs might be similar artefacts made of organic material, of wood, leather or rope; however, these materials by their very nature could not have survived. This idea is backed up by the fact that in many European languages the concept of stirrup contains the original form of this riding aid (cf. W. A. SEABY - P. WOODFIELD, Viking Stirrups, 89. - Ž. TOMIČIĆ, Prilog istraživanju karolinškog oružja u Međimurju, p. 218, n. 36).

${ }^{21}$ L. WHITE Jr., Medieval Technology and Social Change. Oxford, 1962, p. 14-28.

${ }^{22}$ П. П. АЗБЕЛЕВ, Еще раз о ранних стременах, in: Российский археологический ежегодник 4, Санкт-Петербург, 2014, pp. 297-322, gives several monuments on which it is possible to see the very early use of stirrups among the Asian peoples. Reference is made to examples of "proto-stirrups" that go back to the first century CE (for example, from a seal from Pakistan of the $1^{\text {st }}$ century, p. 304, fig. 6 or from a bronze vase from the Kullu valley in northern India of the $3^{\text {rd }}$ century, p. 305, fig. 7).

${ }_{23}$ Both objects are in the British Museum. Сf. П. П. АЗБЕЛЕВ, Еще раз о ранних стременах, for the seal from Pakistan p. 304, fig. 6, and for the vase from India p. 305, fig. 7. - L. WHITE Jr., Medieval Technology, p. 15. n. 1 doubts the authenticity of the Indian vase.

${ }^{24}$ The oldest note of the use of stirrups in Chinese sources goes back to 477 (cf. L. WHІТЕ Jr., Medieval Technology, р. 15. - А. Н. КИРПИЧНИКОВ, Снаряжение всадника и верхового коня, p. 83-84). Also coming from Asia are very old depictions of a war horse with stirrups. On a relief from the mausoleum of Emperor T'ai Cong, from the $7^{\text {th }}$ century (not far from Xi'ana in the Shaanxi province) a nomad warrior is carved, with a well equipped horse; cf. W. MENGHIN, Die Langobarden - Archäologie und Geschichte. Stuttgart, 1985, pp. 86-87, fig. 77. - I. BÓNA, Ungars Völker im 5. und 6. Jahrhundert, in: Germanen, Hunnen und Awaren. Schätze der Völkerwanderungszeit, (ed. W. Menghin, T. Springer, E. Wamers), Nürnberg, 1987, pp. 126-129. In this very realistic depiction it is easy to recognise a deep saddle with ring and stirrups, harness for the sapi and the beast part of the horse and metalfitted harness with bit and reins on his head. Coparing this depiction with data obtained from archaeological excavations - primarily in the Carpathian basin - Menghin ventures that this is a depiction that might be very close to the appearance of an Avar cavalryman. J. Hampel thought something similar when several decades ago he discussed the equipment of the nomadic cavalry and as an illustration provided a relief from a silvered post-Sassanid bowl of the $7^{\text {th }}$ century, which was found in the pre-Ural Russian district of Perm (see: J. HAMPEL, Alterthümer des frühen Mittelalters 1, 272-273, fig. 646). - G. LASZLO, Stepenvolker und Germanen. Kunst der Volkerwanderungszeit. Budapest, 1970, p. 73, fig. 34. For more of this see in: A. MILOŠEVIĆ, Tragovi starih vjerovanja, pp. 44-45, fig. 52, pp. 106-107, fig. 113 .

${ }^{25}$ F. CURTA, Three earliest Avar-age stirrups, or the "stirrup controversy" revisited, in: The Other Europe in the Middle Ages. Avars, Bulgars, Khazars, and Cumans, (ed. F. Curta, R. Kovalev), Leiden - Boston, 2008, pp. 297-326. - F. CURTA, Horsemen in Fronts or Peasants in Villages? Remarks on the Archaeology of Warfare in the $6^{\text {th }}$ to $7^{\text {th }}$ c. Balkans, in: War and Warfare in Late Antiquity, (ed. A. Sarantis, N. Christie), Leiden - Boston, 2013, pp. 8o9-850. ${ }^{26}$ I. BÓNA, Neue Nachbarn im Osten. Die Awaren, in: Die Bajuvaren. Von Severin zu Tassilo 488-788, (ed. H. Dannaheimer, H. Dopsch), München Salzburg, 1988, p. 108. It is stirrups that indicate the ability for cultures to have been mutually assimilated over a wide area from the eastern Merovingian areas to the Carpathian basin at the end of the $6^{\text {th }}$ and in the $7^{\text {th }}$ century, Also, the mingling of other archaeological finds in both of these zones suggests the conclusion that at that time there was a free circulation of goods nad people. In some areas this resulted in an almost total restructuring of economic systems, and partially (at the regional level) in the modification of the indigenous genome of the local people after the not always peaceful integration of various cultures and ethnic groups. For more see in: V. LA SALVIA, Germanic populations and Steppe people (An example of the integration of material cultures. The diffusion of the Stirrup in the eastern Merovingian area), Chronica 11, Szeged, 2012, pp. 88-95. Suchlike general conclusions may serve to explain the uncommon find of a silver damascened pair of stirrups in Zmajevac in Baranya. See n. 24-27).

${ }^{27}$ L. WHITE Jr., Medieval Technology, p. 23. - D. CSALLÁNY, Archäologische Denkmäler der Awarenzeit in Mitteleuropa: Schriftum und Fundorte. Budapest, 1956, pp. 77-220. - V. LA SALVIA Germanic populations, pp. 78-95 (more extensive lit. in n. 3).

${ }^{28}$ L. WHITE Jr., Medieval Technology, pp. 14-28. 

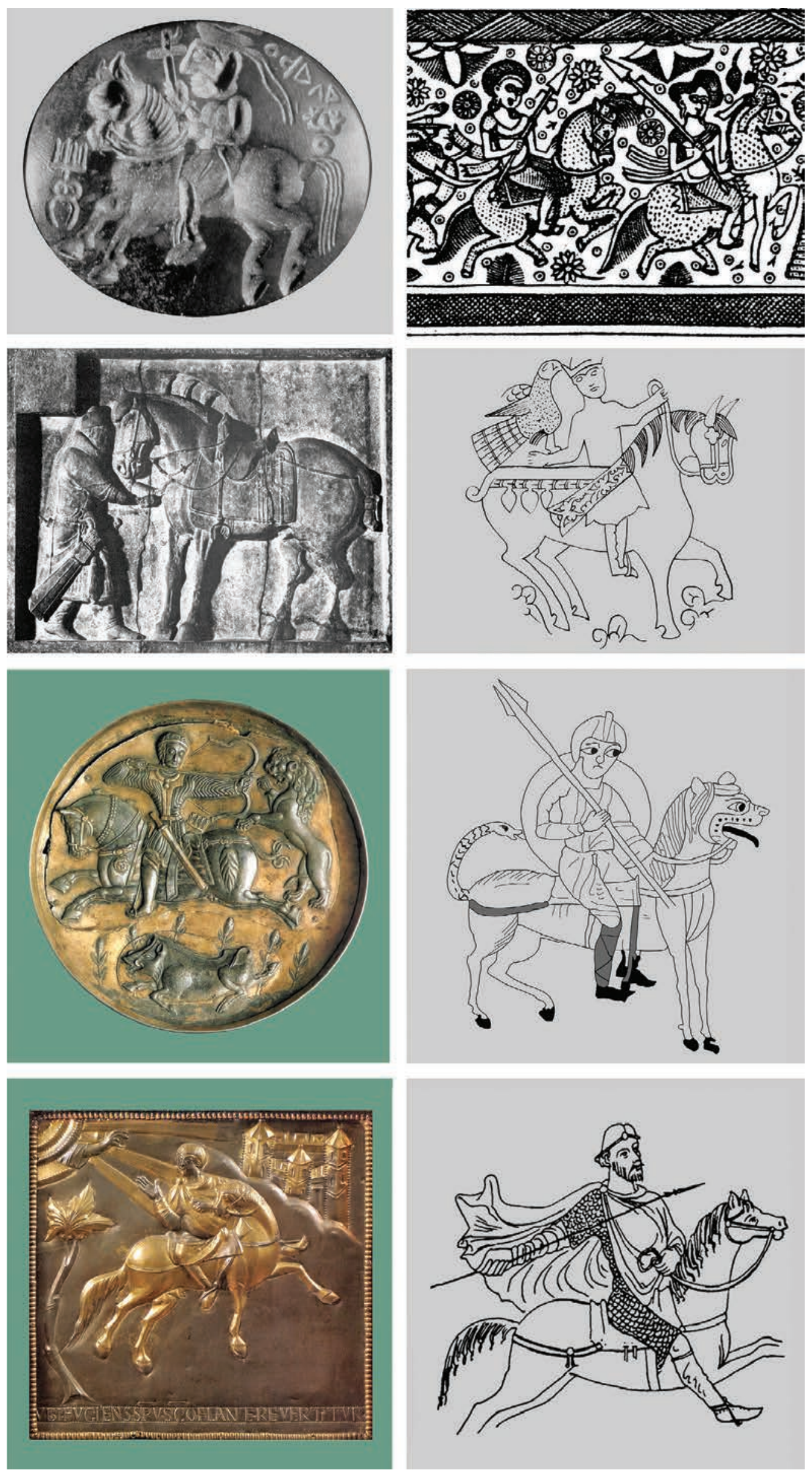

Fig. 3. Stirrups on monuments from the first millennium: 1. Pakistan (after: П. П. Азбелев); 2. India (after: П. П. Азбелев); 3. Xi'ana in the province of Shaanxi in China (after: W. Menghin); 4. Sargatka in Russia (after: G. László); 5. district of Perm in Russia (after: A. Milošević); 6. Valencia-Bibliothèque municipale (drawing: N. Šimundić Bendić, after: M. Schulze Dörrlamm); 7. S. Ambrogio in Milan (after: https://piccolenote.ilgiornale.it); 8. Golden Psalter of S. Gallen (after: A. Н. Кирпичников) 
a mediator that first of all integrated the practical use of the stirrup - from Asia via the Arabs - into its own cavalry, and then, via the themes north of the Black Sea, transmitted it to the cavalry equipment of European men-at-arms ${ }^{29}$. But the archaeological support put forward as confirmation of such an opinion is not entirely convincing, for the earliest, and key, finds, on which such assumptions can be built, come from mixed archaeological contexts that do not permit any simple classification and identification, because of the diverse cultural influences present in these units ${ }^{30}$. The hypothesis of a Byzantine origin for the stirrup would tend to be supported by the fact that from that milieu came the oldest information about this part of horse tack, and in two places it is mentioned in the Strategikon, the authorship of which is ascribed to Emperor Maurice (582-602). According to the writing of Emperor Leo VI (886-911) we know that in his age the stirrup was part of the standard equipment of Byzantine heavy cavalry ${ }^{31}$.

On the basis of available data, it is still difficult to draw a generally acceptable conclusion about the origin of the stirrup in Europe. Both theories, the Avar and the Byzantine, rely on indirect or dubious evidence, because of which their conclusions are untrustworthy. Most probably, as already stated in the literature, the introduction of the stirrup into Europe should be explained as the result of a long process in which new technologies in military equipment were applied, and, as a result, in the techniques of warfare. It is also completely certain that the process started in the $4^{\text {th }}$ or $5^{\text {th }}$ century, in distant Asia, and that through the several ages, not only the Avars might have taken part in it, but also the Byzantines and the Arabs ${ }^{2}$.

Whatever the case may be, it seems incontestable today that stirrups came into wide use in Europe at the turn of the $7^{\text {th }} / 8^{\text {th }}$ century. Such an opinion is based on findings of several cavalry graves from the Germanic area, but it is still unsettled whether they were plunder or gifts from the Avar Khanate, or perhaps imitations, which were created as a result of frequent contacts with the Avars ${ }^{33}$. Finally, L. White, after a brief analysis, concludes that stirrups came into wide use in Western Europe in the first half of the $8^{\text {th }}$ century, in the Charles Martel period (718-741) ${ }^{34}$, which is partially confirmed by archaeological finds 35 . When the French cavalry was reorganised in the early Carolingian period, under the impact of the Vikings, from the end of the $8^{\text {th }}$ century ${ }^{36}$, stirrups gradually came into general use, as shown by many archaeological finds in various European countries, and also in the first visual performances. The earliest such depictions in European art, it is often said, are two equestrian motifs on the golden altar of St Ambrose's in Milan, from about 840 (fig. 3.7) and several miniatures in the Golden Psalter from the monastery of St Gallen of

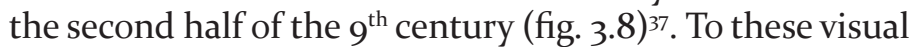
productions we can add a miniature from an early medieval Apocalypse from the first third of the $9^{\text {th }}$ century, showing a warrior who was riding a fantastic animal, his feet in stirrups (fig. 3.6). Since this manuscript is from the first third of the $9^{\text {th }}$ century, it is also one of the earliest depictions of the use of the stirrup in European art ${ }^{38}$.

The numbers of stirrups found in European and Central Asian sites and their diversity long ago inclined experts to deal with their typological classification and chronological determination, and on some occasions with an attempt to group them culturally and regionally. Sometimes there has been an attempt, by the study of this kind of find, to explain possible cultural and mercantile contacts, as well frequent military clashes to which were connected the displacements of different ethnic groups that were associated with a given type of stirrup.

A key contribution to these endeavours was made by great experts and honoured precursors of the turn of the

\footnotetext{
${ }_{29}$ Cs. BÁLINT, Byzantinisches zur Herkunfsfrage des vielteigen Gürtels, in: Kontakte zwischen Iran, Byzanz und der Steppe im 6.-7. Jahrhundert, (ed. Cs. Bálint), Varia Archaeologica Hungarica 10, Budapest, 2000, pp. 99, 101-104, 120-21, 136-38, n. 117-127. - Cs. BÁLINT, Zur Geschichte und Archäologie der osteuropäischen Reiterhirten im Frühmittelalter, in: Reitervölker aus dem Osten. Hunnen und Awaren, (ed. F. Daim), Bad Vöslau, 1996, pp. 202-204. - Cs. BÁLINT, Über die Datierung der osteuropäischen Steppenfunde des frühen Mittelalters (Schwierigkeiten und Möglichkeiten), Mittelungen des archäologische Insitut der Ungarische Akadamie des Wissenschaften 14, Budapest, 1985, pp. 137-47. - Cs. BÁLINT, Die Archäologie der Steppe. Steppenvölker zwischen Wolga und Donau von 6. bis 9. Jahrhunderts. Vienna-Cologne, 1989.

$3^{\circ}$ V. LA SALVIA, Germanic populations, pp. 78-79.

${ }^{31}$ L. WHITE Jr., Medieval Technology, pp. 20, 26.

${ }^{2}$ B. S. BACHARACH, A picture of Avar-Frankish Warfare from a Carolingian Psalter of the Early Ninth Century in Light of the Strategikon, Archivum Eurasie Medii Aevi 4, Wiesbaden, 1984, pp. 5-27. - B. GENITO, Sepolture con cavallo da Vicenne (CB): un rituale nomadico di origine centroasiatica, in: I Congresso Nazionale di Archeologia Medievale, Pisa, 29-31 maggio 1997, (ed. S. Gelichi), Florence, 1997, p. 287.

33 W. WECK, Die Alamannen in Württemberg, Germanische Denkmäler der Völkerwanderungšeit 1, Berlin, 1931, p. 75. - H. MÜLLER KARPE, Gräber der Urnenfelder - und Frühhallstattkultur aus der Gegend von Marburg, in: Hessische Funde von der Altsteinzeit bis zum frühen Mittelalter, Schriften zur Urgeschichte. Hessisches Landesmuseum Kassel 2, (ed. H. Müller Karpe), Marburg, 1949, pp. 29-45. - L. WHITE Jr., Medieval Technology, pp. $23-25$.

${ }^{34}$ L. WHITE Jr., Medieval Technology, p. 27. - W. A. SEABY - P. WOODFIELD, Viking Stirrups, p. 89. Archaeological evidence is adduced for stirrups first being used on a large scale and adopted in a big reorganisation of the Merovingian army in the first half of the $8^{\text {th }}$ century and that the use of the stirrup contributed to the victory of Charles Martel over the Muslim forces at the Battle of Poitiers (Tours).

35 W. A. SEABY - P. WOODFIELD, Viking Stirrups, p. 89. - F. STEIN, Adelsgraber des Achten Jahrhunderts, p. 85.

${ }^{36}$ W. A. SEABY - P. WOODFIELD, Viking Stirrups, pp. 89-94.

${ }^{37}$ L. WHITE Jr., Medieval Technology, p. 26. - C. HAHN, Narrative on the Golden Altar of Sant'Ambrogio in Milan: Presentation and Reception, Dumbarton Oaks Papers 53, Washington, 1999, pp. 167-187. - J. HUBERT - J. PORCHER - W. F. VOLBACH, L'Empire carolingien. Paris, 1968, pp. $240-246$.

$3^{8}$ Valencija - Bibliothèque municipale, Ms. 99, fol. 19r for which cf.: M. SCHULZE-DÖRRLAMM, Zwei ungewöhnliche Bronzeschlüssel der Karolingerzeit - ein Amulettschlüssel aus Mainz und ein „Petrusschlüssel“ aus Alzey, in: Grosso Modo - Quellen und Funde aus Spätantike und Mittelalter: Festschrift für Gerhard Fingerlin zum 75. Geburtstag, (ed. N. Krohn, U. Koch), Forschungen zu Spätantike und Mittelalter 1,Weinstadt, 2012, pp. 193-194, fig. 3.

${ }_{39}$ A. SCHLIEBEN, Geschichte des Steigbügel, Annalen des Vereinsfur Nassauische Altertumskunde und Geschichisforschung 24, Wiesbaden, 1892. - R. ZSCHILLE - R. FORRER, Die Steigbügel in ihrer Formen- Entwicklung. Caracterisierung und Datirung der Steigbügel unserer Culturvölker. Berlin, 1896, (reprint). - J. HAMPEL, Alterthümer des frühen Mittellalters, Vol. I, pp. 217-242.
} 
$19^{\text {th }}$ and $20^{\text {th }}$ centuries, A. Schlieben, Z. Schile, R. Forrer and J. Hampel ${ }^{39}$ and on the basis of their work by P. Reinecke, E. M. Jope and L. T. White Jr. ${ }^{40}$. From the second half of the $20^{\text {th }}$ century the literature about these issues has increased enormously, on the whole respecting the regional principle as the beginning of the debate. Thus, along with a large number of discussions published about individual finds, there have been studies of examples of stirrups from England ${ }^{41}$, from the Germanic and Scandinavian area ${ }^{42}$, from Transylvania ${ }^{43}$, from the central Danube valley ${ }^{44}$, from Poland 45 and the central Asian (Russian) space ${ }^{46}$, of proto-Bulgarian stirrups $^{47}$, stirrups from Slovenia ${ }^{48}$ and Greater Moravia ${ }^{49} \ldots$

Not a single one of these discussions of typology and chronology of medieval stirrups, selected and relevant to our discussion though they are ${ }^{50}$, gives a simple answer to the question of the type and time to which the specimen from Bribir might belong. Still, with an analysis of individual details, which are referential for typological determination, our opinion is that it can be discussed as a product of the Early Middle Age. The markedly triangular shape is an important marker from this point of view. Such shapes on the whole belong to the early medieval period, from the end of the $8^{\text {th }}$ to the end of the $9^{\text {th }}$ century, and have been found in a string of sites, from the Steppes to Western and Northern Europe ${ }^{51}$. On them there are on the whole mainly plates with a hole for the leather, with the geographically closest analogies in the early Carolingian stirrups from Slovenia ${ }^{52}$. Their opulent tread is straight or bent, concavely or convexly. An important detail on the Bribir stirrup is the thickening at the bottom of the arms, at the join with the straight hammered tread, which is proper to northern European finds of the $10^{\text {th }}$ and early $11^{\text {th }}$ century (fig. 4$)^{53}$. In a typological sense, the Bribir stirrup of a marked triangular shape, as compared with European examples, shows a simpler form, which could bea reason to date it earlier. The round perforations at the joins of the arms of the stirrup and the plate for the leather strap have no analogies in medieval examples.

The specific feature of the Bribir stirrup is its decorativeness. Originally the whole of the outer face of it was ornamented, the lower side of the tread, and the plate for the strap. The decoration has been almost completely effaced from the arms and is preserved only in traces. It can be guessed that it was done with silver damascene wire. The lower side of the tread was done in the same technique, being

${ }_{40}$ P. REINECKE, Zur Geschichte des Steigbügels, Germania 17/3, Berlin, 1933. pp. 220-222. - E. M. JOPE, Agricultural Implements, in: The Mediterranean Civilizations and the Middle Ages, (ed. Ch. Singer, E. J. Holmyard, A. R. Hall, T. I. Williams), A History of Technology 2, Oxford, 1956, pp. 81-102. - L. WHITE Jr., Medieval Technology, pp. 1-38.

${ }^{41}$ W. A. SEABY - P. WOODFIELD, Viking Stirrups, pp. 87-122.

${ }^{42}$ N. GOSSLER, Die mittelalterlichen Steigbügel, p. 109-215. - N. GOSSLER, Reiter und Ritter - Formenkunde, Chronologie, Verwendung und gesellschaftliche Bedeutung des mittelalterlichen Reitzubehörs aus Deutschland. Schwerin, 2011, pp. 145-146. - N. GOSSLER, Wikingerzeitliche Waffen und Reitzubehörfunde aus dem Berliner Bestand der Prussia-Sammlung (ehemals Königsberg/Ostpreußen) und ihre Beziehung zu Skandinavien, Acta Praehistorica et Archaeologica 46, Berlin, 2014, pp. 1-26.

${ }^{43}$ E. GÁLL, An attempt to classify the stirrups dating from the $10^{\text {th }}$ century and the first quarter of the $11^{\text {th }}$ century in the Transylvanian Basin, the Crișana/ Partium and the Banat with an outlook to the Carpathian Basin, in: Warriors, Weapons and Harness from the $5^{\text {th }}-10^{\text {th }}$ centuries in the Carpathian Basin, (ed. C. Cosma), Cluj - Napoca, 2015, pp. 355-406.

${ }^{44}$ CS. BÁLINT, Die Archäologie der Steppe, in: Steppenvölker zwischen Volga und Donau vom 6. bis zum 1o. Jahrhundert, (ed. F. Daim), Wien - Köln - Böhlau, 1989. - M. SCHULZE DÖRRLAMM, Untersuchungen zur Herkunft der Ungarn, pp. 425-438, list of sites on pp. 470-471.

${ }^{45}$ D. NOWAKOWSKA CWETSCH, Strzemiona z terenu Polski (do XIV wieku): próba typologii, Światowit 35, Waršawa, 1986, pp. 65-81. - W. ŚWIĘTOSŁAWSKI, Strzemiona średniowiečne z ziem Polski. Łódź, 1990, on the origin and typology of stirrups on pp. 20-33.

${ }^{46}$ Russian literature about the stirrups of the Early Middle age is like the steppes in its vastness and immensity. In the whole of this great expanse, we would mention: А. Н. КИРПИЧНИКОВ, Снаряжение всадника и верхового коня, pp. 83-116, figs. 65-68. - А. К. АМБРОЗ, Стремена и сёдла раннего средневековья как хронологический показатель (IV-VIII вв.), Советская археология 4, Москва, 1973, pp. 81-86. - С. В. НЕВЕРОВ, Стремена Верхнего Приобья в VII-XII вв. (классификация и типология), in: Снаряжение верхового коня на Алтае в раннем железном веке и средневековье, Алтайский государственный университет, Барнаул, 1998, pp. 129-151. - А. КРЫГАНОВ, Восточноевропейские кочевнические стремена вторй половины VII-X вв., Вестник Харьковского университета, 343, история, вып., 23, Ха́рьков, 1989, pp. 92-121.

47 В. ЙОТОВ, Стремената на прабългарите, pp. 125-134, with a typology of stirrups of Byzantine origin from the $7^{\text {th }}$ to $11^{\text {th }}$ century in Bulgaria. There are interesting damascened stirrups from Varna, today in the Archaeological Museum in Sofia, dated to the end of the $8^{\text {th }}$ and the $9^{\text {th }}$ century, p. 131, fig. 8. - B. ЙОТОВ, Относно датировката на сборната находка от Стрежево, Битолско, in: Проблеми на прабьлгарската история и култура 42, София, 2007, pp. 173-182. - П. В. КРАСИЛЬНИКОВ, К вопросу о типологии стремян с памятников раннебулгарского времени, in: Труды Камской археологоэтнографической экспедиции, Пермь, 2012, pp. 360-367.

${ }^{48}$ Š. KARO, Die Typologie der frühmittelalterlichen Steigbügel aus slowenischen, pp. 165-173.

${ }^{49}$ A. RUTTKAY, Waffen und Reiterausrüstung, pp. 353-356. - Z. MĚCHUROVÁ,Třmeny a jiné součásti sedla z časně středověkého období, Časopis Moravského muzea v Brně 68, Brno, 1983, pp. 61-87. - A. BARTOŠKOVÁ, Slovanské depoty železných předmětů v Československu, Studie archeologického ústavu Československé akademie Věd, Praha, 1986. - M. SCHULZE DÖRRLAMM, Untersuchungen zur Herkunft der Ungarn, pp. 425-438.

${ }^{50}$ See n. 49-59. The main reference indicators for their typological determination are the basic shape of the stirrups, the appearance of the lugs or plates with a hole through which to draw the leathers and the form of the wrought tread. Not a single one of these indicators is specific for just one type, for they are used in variations and combinations.

${ }^{51}$ С. В. НЕВЕРОВ, Стремена Верхнего Приобья, р. 130 (Class I, types 1 and 2). - N. GOSSLER, Die mittelalterlichen Steigbügel, pp. 114-116, 127-130 (Type A I). - N. GOSSLER, Wikingerzeitliche Waffen, pp. 2-5. - W. A. SEABY - P. WOODFIELD, Viking Stirrups, pp. 87-122.

${ }_{52}$ Š. KARO, Die Typologie der frühmittelalterlichen Steigbügel aus slowenischen, pp. 167-169, figs. 3-4 (examples defined as Type 2 and dated to the end of the $8^{\text {th }}$ and the early $9^{\text {th }}$ century).

${ }_{53}$ W. A. SEABY, Late Dark Age Finds from the Cherwell and Ray, 1876-86, Oxoniensia 15, Oxford, 1950, pp. 33-34, 38-39, fig. 14, T. VI/A. - W. A. SEABY - P. WOODFIELD, Viking Stirrups, fig. 4-10. This thickened detail was long ago noted as an important feature of Nordic stirrups of the Carolingian age by R. ZSCHILLE - R. FORRER, Die Steigbügel, pp. 4-6, fig. 3 . 

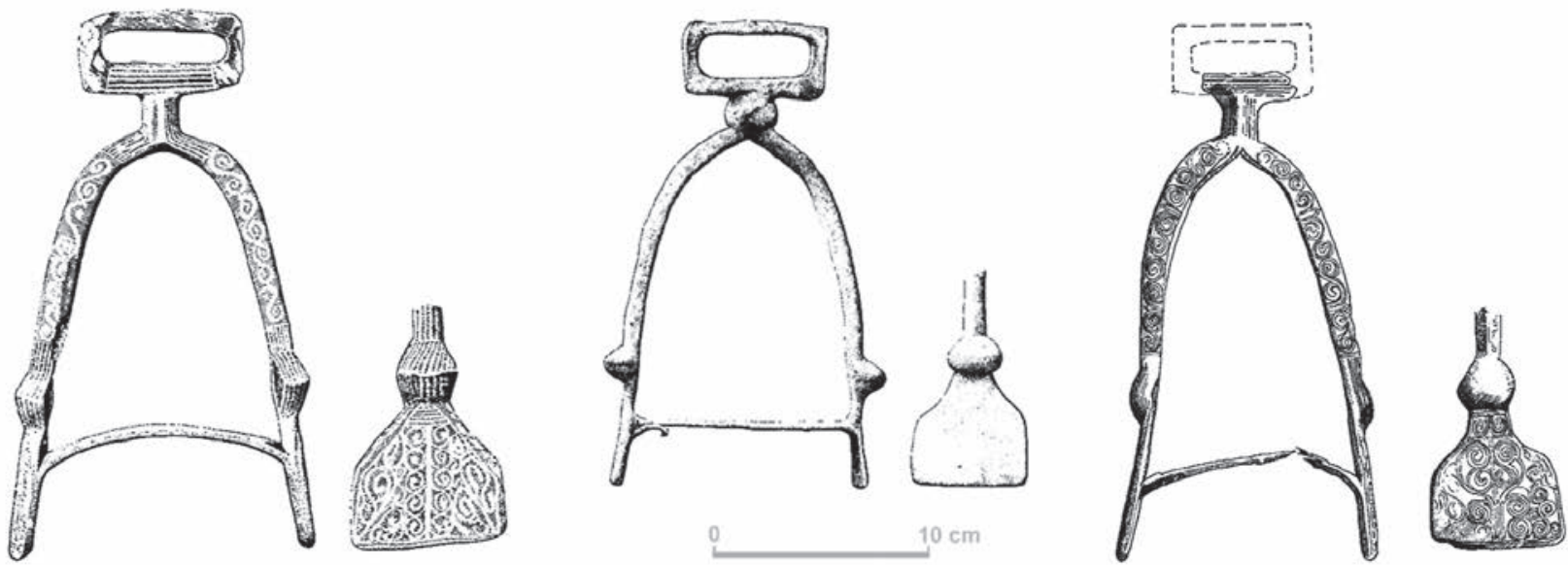

Fig. 4. Viking stirrups from England (after: W. A. Seaby, P. Woodfield)

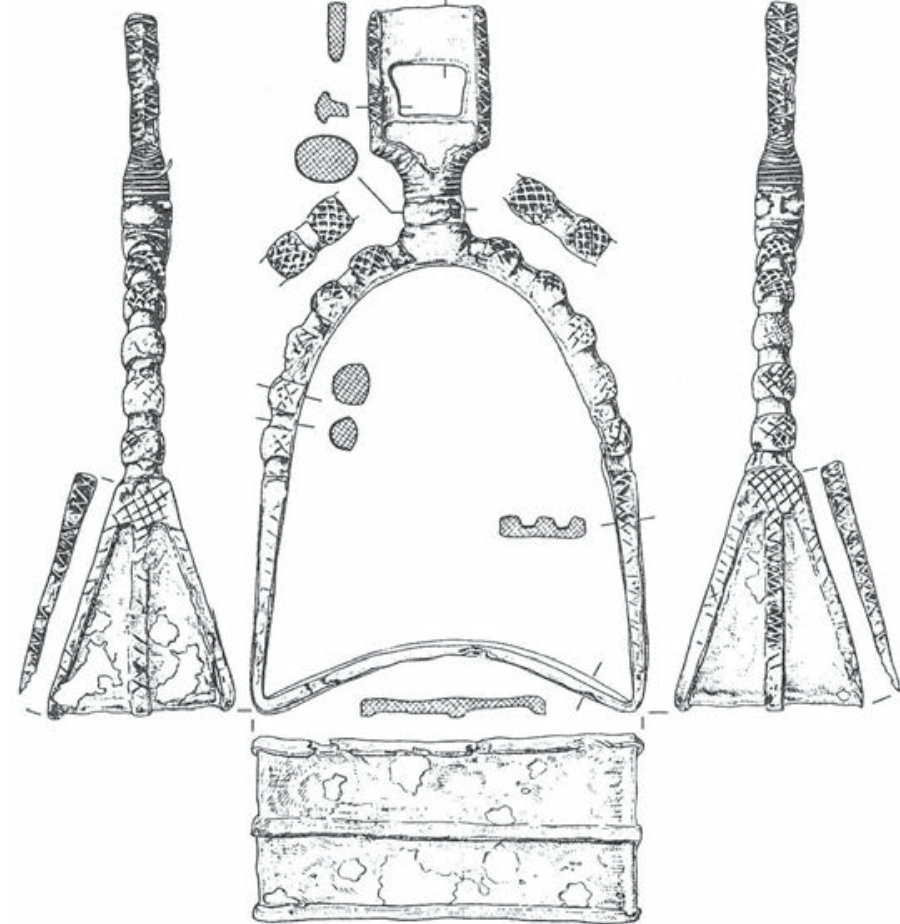

Fig. 5. Early medieval stirrup from Celje decorated with a damascened lattice ornament (after $\breve{S}$. Karo)

entirely covered with diagonal network of small regular squares (fig. 2.4). One early Carolingian stirrup from Celje, Slovenia (fig. 5) ${ }^{54}$ is decorated in the same technique and with a similar ornamentation, and a very good analogy for our Bribir specimen is a $9^{\text {th }}$ century Swiss stirrup, the strap plate of which is also decorated with a silver diagonal reticulation. Particularly interesting for us is that this stirrup has a markedly triangular shape and a thickening at the joins of the arcs with the hammered out tread (fig. 6.2)55. The same diagonal reticulated ornament is also produced with damascened brass wire on the pommel of a sword from Hessen in Germany (fig. 6.1) ${ }^{56}$.

The most complexly ornamented is the outer side of the plate of the Bribir stirrup (fig. 7, 8). The whole surface of it is decorated with various motifs produced in damascening


Fig. 6. Early medieval products decorated with damascened lattice ornamentation: 1. late Merovingian sword pommel (after: 799 - Kunst und Kultur); 2. early Carolingian stirrup from Switzerland decorated with lattice ornamentation (after: Z. Schille, R. Forrer)

with gold and silver wire. The central silver motif is composed of two opposed headless birds placed in a triangle, perhaps modelled on early medieval gables of roodscreens on which birds are placed in just the same way at the sides of

\footnotetext{
$\overline{54}$ Š. KARO, Die Typologie der frühmittelalterlichen Steigbügel aus slowenischen, p. 168-169, fig. 4/1.

55 R. ZSCHILLE - R. FORRER, Die Steigbügel, p. 20, T. I.20.

${ }^{56} 799$ - Kunst und Kultur der Karolingerzeit. Karl der Große und Papst Leo III. in Paderborn. Bd. 1, (ed. Ch. Stiegemann, M. Wemhof), Paderborn, 1999, pp. 279-28o, cat. entry V.17.
} 

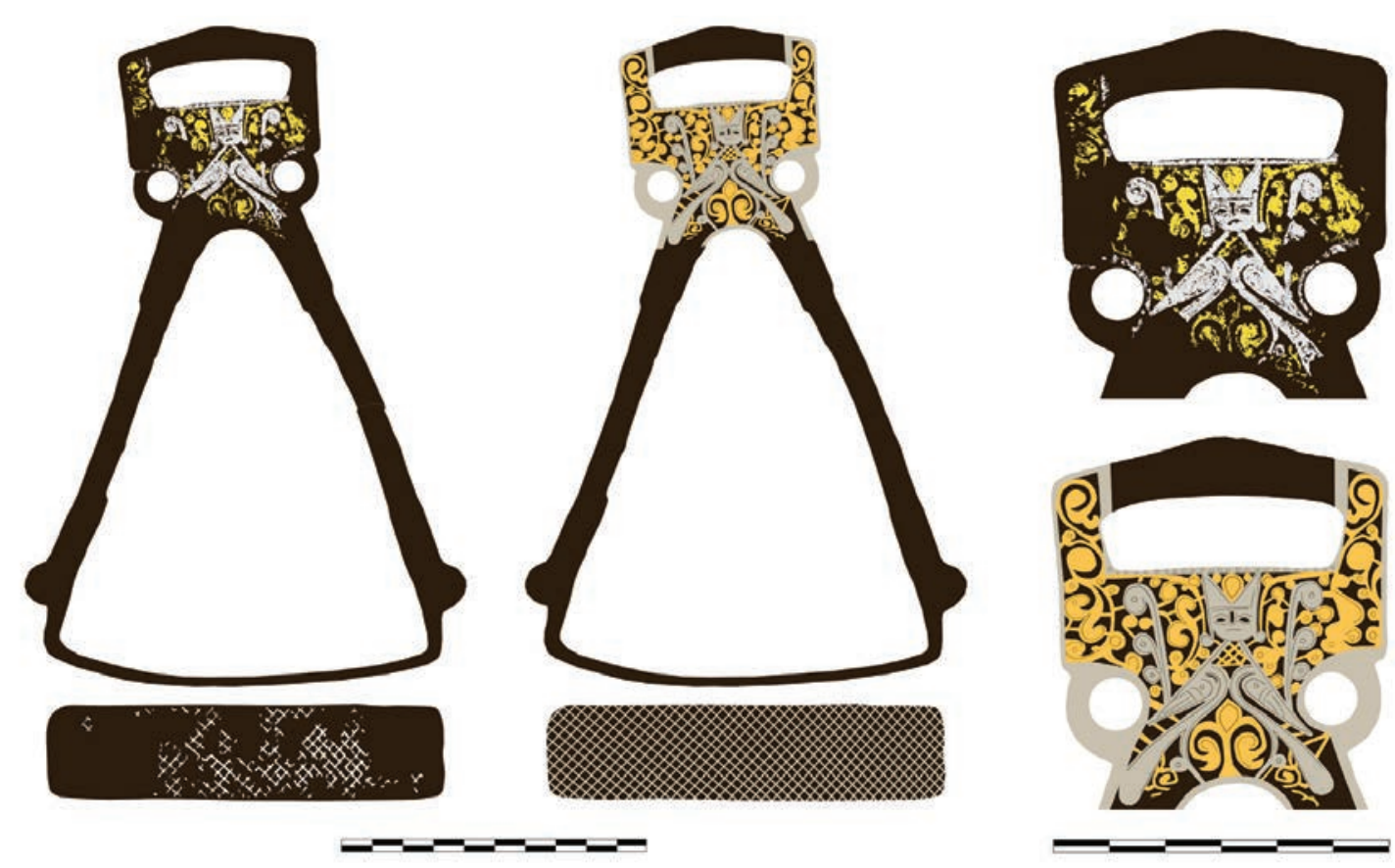

Fig. 8. Bribir stirrup (reconstruction of the decoration: D. Popovič)

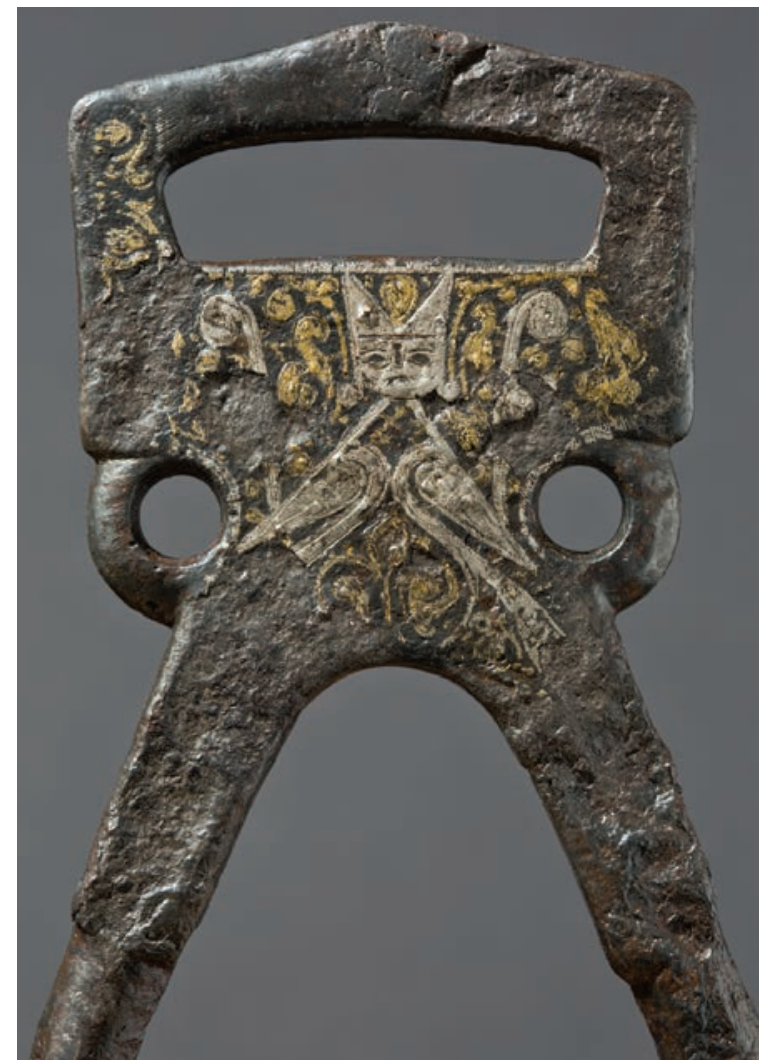

Fig. 7. Bribir stirrup: decorated plate for leathers (photograph: A. Z. Alajbeg) a cross, the most frequent iconographic motif. At the peak of a triangle so formed is placed a crowned male head, with a crown of the open type, with pendants or a part that covers the head on both sides, in a manner similar to that found in a large number of examples on imperial Byzantine coins ${ }^{57}$, and also on the well-known altar screen that is today incorporated into the Split baptistery ${ }^{58}$. A very good comparison is also the crown on the head of a rider engraved on a cut platter from the Yamal Peninsula in northern Russia (fig. 9) ${ }^{59}$, which perhaps starts up other research possibilities. The rest of the space of the plate, applying the principle of horror of the vacuum, is filled up with plant and tendril ornaments done with damascened gold wire.

For the temporal and cultural determination of the Bribir stirrup, the technique of decoration could well be interesting, that is, the gold and silver wire damascening. In the European Early Middle Age, it was used more and more from the Merovingian period on, particularly central Europe and Scandinavia, most often on artefacts that belonged to harness and the accoutrements of riders ${ }^{60}$. In a reduced extent, objects of the same kind were damascened in the later centuries of the Early Middle Age. We would refer, as the closest find geographically, to a pair of iron spurs with a partially preserved fastening set from Biskupija by $\mathrm{Knin}^{61}$ and to early Carolingian swords from Žeževica and Koljane (fig. 10) ${ }^{62}$. We have already mentioned the Celje stirrup (fig. 5). To it should be added several products from Greater Moravia

\footnotetext{
${ }^{77}$ Ph. GRIERSON, Byzantine Coinage. Washington D.C., 1999, p. 29.

${ }^{58}$ V. KLAIĆ, Kruna kralja Tomislava, in: Crtice iz hrvatske prošlosti, (ed. J. Nagy), Zagreb, 1928, pp. 88-90. - I. GUBERINA, O postanku hrvatske krune. (Viest X. vieka o slici 'nedavno umrloga kralja'), Hrvatska revija 16/1, Zagreb, 1943, pp. 1-14. - LJ. KARAMAN, Još o kruni hrvatskih kralieva, Obzor 78-84/73, Zagreb, 1932. - I. FISKOVIĆ, Reljef kralja Petra Krešimira IV., Starohrvatska prosvjeta, ser. 3, vol. 28-29, Split, 2002, pp. $24-25$.

59 Н. В. ФЕДОРОВА, Торевтика Волжской Болгарии. Серебряные изделия X-XIV вв. из зауральских коллекций, Труды Камской археологической экспедиции, Вып. 3. Пермь, 2003, pp. 141-142, fig. 6 . Dated variously to the $8^{\text {th }}$ or to the $10^{\text {th }}$ and $11^{\text {th }}$ centuries.

${ }^{60}$ H. ROTH, Kunst und Handwerk im frühen Mittelalter. Stuttgart, 1986, pp. 41-43, 53-54. - Tauschierarbeiten der Merowingerzeit. (Ed. W. Menghin), Berlin, 1994.

${ }^{61}$ A. MILOŠEVIĆ, Karolinški utjecaji u Hrvatskoj kneževini u svjetlu arheoloških nalaza, in: Hrvati i Karolinzi. Rasprave i vrela. (Ed. A. Milošević), Split, 2000, pp. 121-122. - Hrvati i Karolinzi. Katalog, cat. no. IV.45, pp. 216-217.

${ }^{62}$ For the Žeževica sword see: Hrvati i Karolinzi. Katalog, cat. entry IV. 26o, pp. 356-358. - A. PITEŠA, Katalog nalaza iz vremena seobe naroda, srednjeg i novog vijeka u Arheološkome muzeju u Splitu. Split, 2009, pp. 53-55, and for the Koljano sword, see in: A. MILOŠEVIĆ, Novi mač iz Koljana, pp. 459-470.
} 


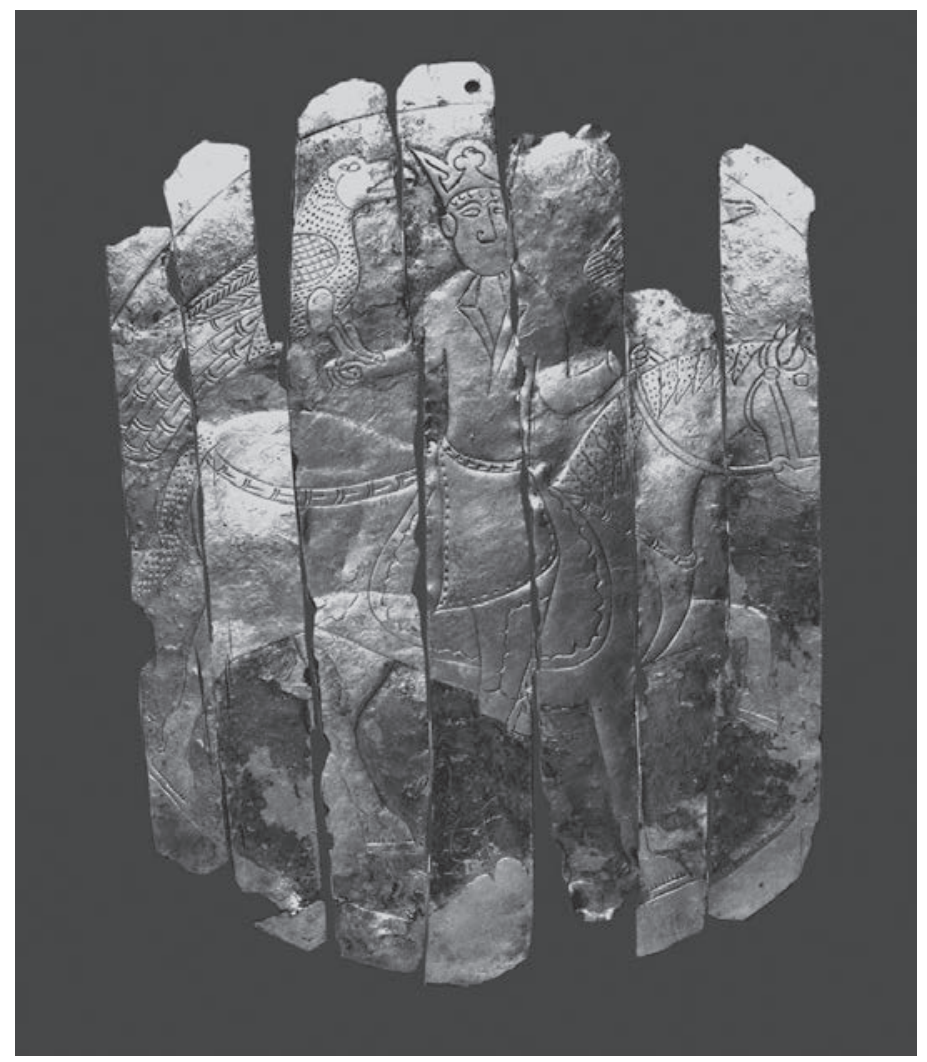

Fig. 9. Rider with crown on a cut silver platter from Yamal Peninsula, northern Russia (after: N. F. Fedorova)
Duchy $^{63}$, objects from other parts of the Carolingian Empire ${ }^{64}$ and finds from Scandinavia and England ${ }^{65}$.

It is impossible to say at the moment with any certainty whether the Bribir stirrup originated in a workshop in one of these regions, or whether it was made under the influence of them ${ }^{66}$, but it is very probable that it is an early medieval product, without direct analogies in similar objects of the time in Europe. The decoration technique and particularly the shape of the stirrup are the reasons for this kind of thinking, although we must be aware that artefacts of warfare were decorated in a similar way in the later centuries of the Middle Ages. A very good example of this is the decorated maces from the Balkan sites that were once part of the Byzantine Empire (fig. 11) ${ }^{67}$. But however further study of the Bribir stirrup finally ends up, we believe that it will not get out of the temporal framework bounded by the $9^{\text {th }}$ and $11^{\text {th }}$ century. At this moment, since this is a unique finding of a stirrup and in terms of its luxurious workmanship is worthy of some early medieval Bribir princeps, it was not part of our remit to evaluate it definitively in terms of time and culture, rather to start up a debate about it, and once again to draw attention to Bribir as a very important archaeological site in which any archaeological effort will pay off handsomely.

The examples of cavalry equipment that we discuss here have made a considerable contribution to illuminating the past of Bribir, but with their cultural indicators they have not gone outside the framework that is known to us about this site from earlier and other finds of the early medieval
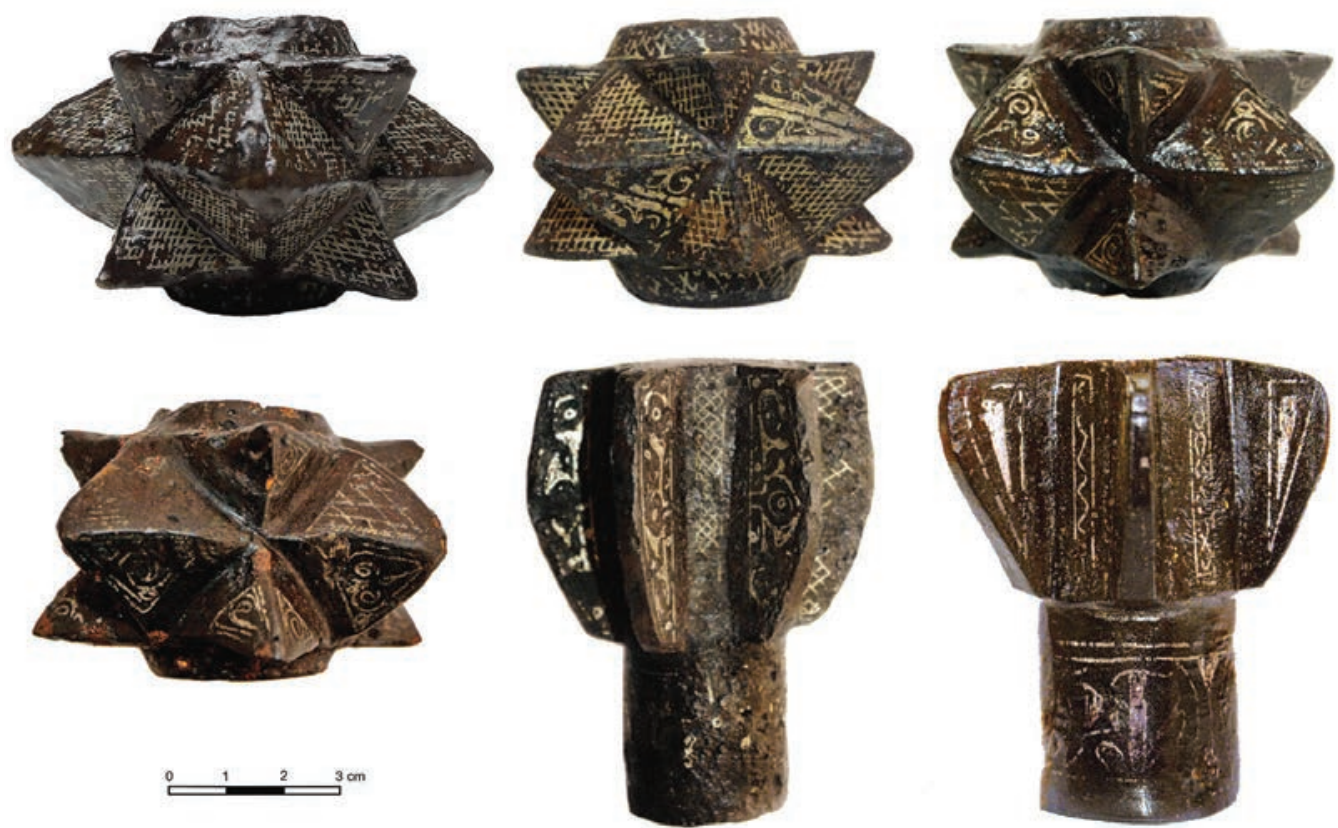

Fig. 11. Maces decorated with damascening: 1. Balkan part of the Danube valley (after: R. D'Amato); 2-6. Bulgaria, Vatevi Collection (after: S. Popov)

- A. MILOŠEVIĆ, The K-type Sword from Koljane in Dalmatia as Possible Evidence for the Arrival of Croats at the End of the 8th Century, in: Croatia at the Crossroads: A consideration of archaeological and historical connectivity. Proceedings of a conference held at Europe House, Smith Square, London, 24-25 June 2013 to mark the accession of Croatia to the European Union, (ed. D. Davison, V. Gaffney, P. Miracle, J. Sofaer), Oxford, Archaeopress Publishing Ltd., 2016. pp. 207-221.

${ }^{63}$ E.g. Great Moravia and the Beginnings of Christianity, pp. 327, 344, 345, 369, 370, 373, 374, 376.

${ }^{64}$ Npr. R. ZSCHILLE - R. FORRER, Die Steigbugel, T. I.1-2, II. 1-3, 5. - F. STEIN, Adelsgraber des Achten Jahrhunderts, T. 58/3-4, 66/2-3, 75, 79, 80, 81, 85, 88.

${ }^{65}$ Npr. W. A. SEABY - P. WOODFIELD, Viking Stirrups, pp. 87-122. - N. GOSSLER, Wikingerzeitliche Waffen, pp. 2-4. - M. KARA, Frühmittelalterliches Grab eines bewaffneten Kaufmannes aus dem ort Ciepłe (Warmhof) in danziger Pommern im Lichte einer erneuten Analyse, Acta universitatis Lodyiensis, Folia archaeologica 23, Łódź, 2001, pp. 136-139.

${ }^{66}$ Perhaps interesting from this point of view is a fragment of a stirrup decorated in Scandinavian Borre-style, found in an early medieval grave on the Samland/Sambia peninsula in the Kaliningrad district (cf. N. GOSSLER, Wikingerzeitliche Waffen, pp. 4-6, fig. 3).

${ }^{67}$ And example is provided by R. D'AMATO, The war-mace of Byzantium, the $9^{\text {th }}-15^{\text {th }} \mathrm{c}$. AD. New evidence from the Balkans in the collection of the World Museum of Man, Florida, Acta Militaria Mediaevalia 7, Kraków - Rzešów - Sanok, 2011, pp. 38, 40, fig. 23.5. This iron specimen decorated with a damascened 

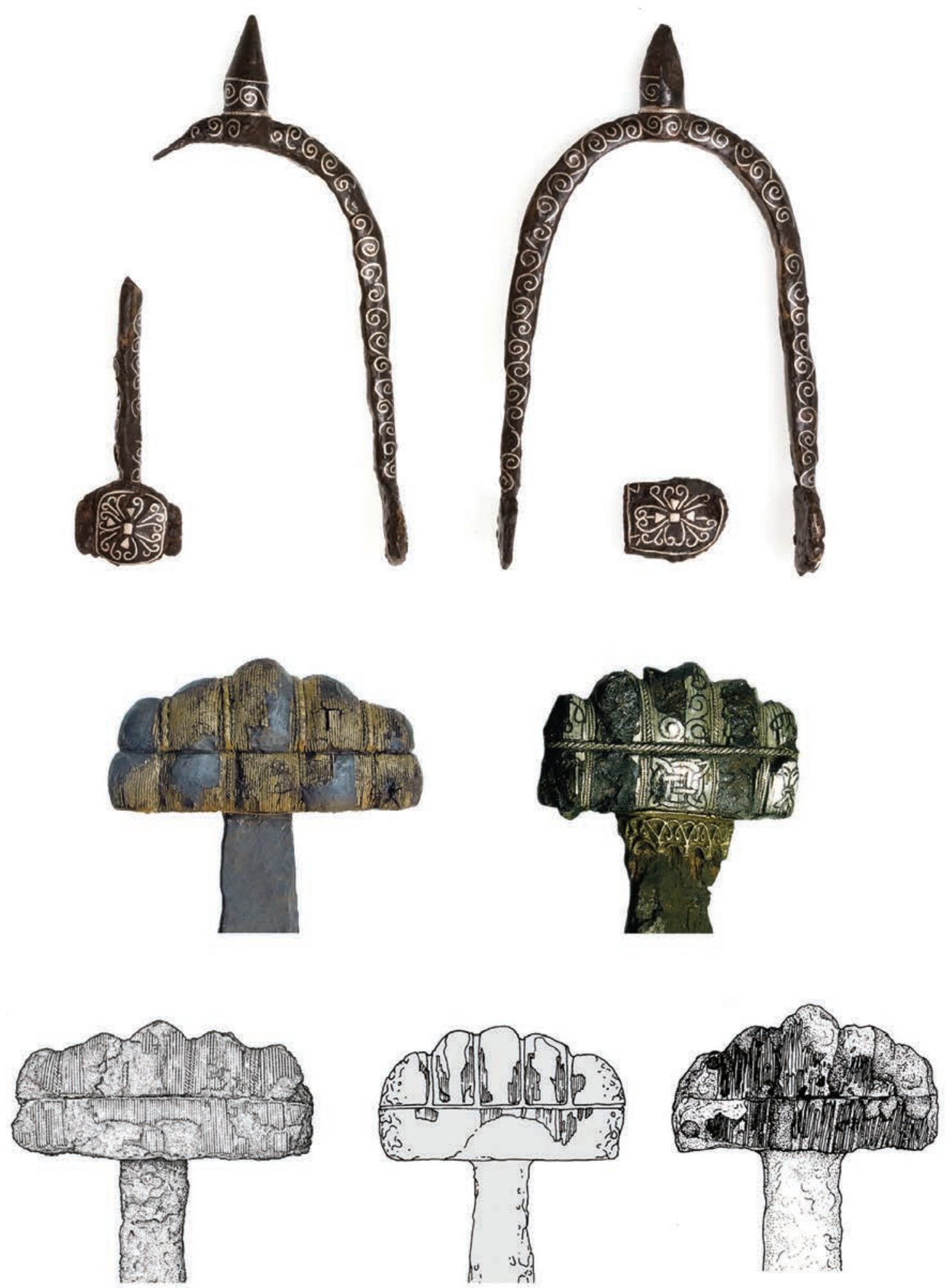

Fig. 10. Early medieval products decorated with damascened silver and brass wires: 1. spurs from Biskupija by Knin (photograph: A. Z. Alajbeg); 2. sword pommel from Koljane (photograph: M. Rogošić); 3-4. sword pommels from Haithabu (after: E. Wamers); 5-6. sword pommels from Mikulčici (after: J. Košta)

period $^{68}$. With typological and chronological analysis we also wanted to show the different influences under which these objects were created or directly imported from the big workshop centres in central Europe and the Byzantine Empire. Their quality and excellent workmanship docu- ments the high level of life at Bribir in the centuries in which the nobiles Breberienses started their economic, military and political rise.

silver lattice is said to have been found in the Balkan part of the Danube valley. It is hypothesised to have belonged to a senior officer in the period between the end of the $12^{\text {th }}$ and the $14^{\text {th }}$ century. A number of similarly decorated maces from Bulgaria are cited by S. POPOV, The Maces from the Present Bulgarian Lands (10 ${ }^{\text {th }}-17^{\text {th }}$ c. AD). Vatevi Collection. Sofia, 2015, p. 296-297, cat. no. 296, 297, p. 298, cat. no. 299, p. 280, cat. no. 414, p. 404, cat. no. 448. On the whole they are dated to the $13^{\text {th }}$ to $14^{\text {th }}$ centuries.

${ }^{68}$ Articles of T. Burić, V. Delonga, M. Dragičević and M. Zekan in: Bribir u srednjem vijeku, (ed. A. Milošević), Split, 1995. 